\title{
EPILOGUE: UPDATES TO RESEARCH IN SOCIAL MOVEMENTS, CONFLICTS, AND CHANGE
}

\section{Lisa Leitz}

Research in Social Movements, Conflicts and Change has a distinguished history of publishing innovative research on international wars, peace efforts, protests, and other mechanisms for social change. I look forward to upholding this tradition as its third editor. RSMCC offers a unique academic bridge in which scholars in the nonviolence and social movement traditions converge and their scholarship merges with conflict analysis and peacebuilding research. By bringing together these interdisciplinary scholars, RSMCC incubates novel and rich theoretical insights.

In an effort to expand the diverse pool of international scholars who read and contribute to the series as both authors and readers, and to continue the high quality of submissions while seeking to increase the number of volumes we produce per year, I have established an Editorial Board for RSMCC. Please join me in welcoming these scholars, and if you have an interest in contributing to this work, consider joining our team. The inaugural RSMCC Editorial Board members are:

Lisa Leitz, $\mathrm{PhD}$

Editor-in-Chief

Delp-Wilkinson Endowed Chair in Peace Studies, Chapman University Eitan Alimi, $\mathrm{PhD}$

Associate Professor, Department of Sociology and Anthropology, The Hebrew University of Jerusalem

Joel Busher, PhD

Associate Professor, Centre for Trust, Peace and Social Relations, Coventry University

Darren Kew, PhD

Chair of the Department of Conflict Resolution, Human Security, and Global Governance and Executive Director of the Center for Peace, Democracy, and Development, University of Massachusetts Boston 
Cécile Mouly, $\mathrm{PhD}$

Professor and Coordinator of the Research Group in Peace and Conflict at FLACSO (Facultad Latinoamericana de Ciencias Sociales) Ecuador

Patrick Coy, $\mathrm{PhD}$

Editor Emeritus

Professor, School of Peace and Conflict Studies, Kent State University

I finish this volume amidst the coronavirus pandemic, which has closed borders and created social isolation, potentially deepening or creating international conflicts and increasing ethnonationalism. Those hardest hit by the effects of the virus are minority racial groups, the economically disadvantaged, and people with disabilities, highlighting the consequences of various inequalities in many societies. At the same time, large and diverse crowds, often with masked protestors, have taken to the streets around the globe to demand racial justice. These movements offer examples of innovative online protest tactics and demonstrate how dramatic social disruption provides opportunities for making positive social change to enduring injustices.

Given the calls to recognize the effects of race on minority scholars, and the need for further research and theory on the impact of race on wars, peacebuilding, and activism, I commit RSMCC to being part of the solution. First, as stated in the Introduction, a section of Volume 46 is reserved for analyses of race and racial justice movements. Second, I commit the series to increasing the diversity of our authors, reviewers, and editorial board to ensure that Black and other minority scholars are part of both the decisionmaking and authorship of RSMCC's future scholarship. Finally, like Greg Maney, to whom Volume 43 was dedicated, I have a deep commitment to examining how social movement scholarship can be better integrated with ongoing movements for social justice and democracy. The Editorial Board is considering proposals for broadening the series to achieve this work. Submissions to future Volumes and proposals for topically focused Special Issues can be sent to me at rsmcc@chapman.edu or leitz@chapman.edu. 